\title{
ПОВЕКЕСЛОЈНА ТВОРЕЧКА АКТУАЛИЗАЦИЈА (ПОЕТСКИОТ ДИСКУРС ВО ДВОЈАЗИЧНАТА ЗБИРКА МЕЛАНХОЛИЈА ОД ЕРОЛ ТУФАН)
}

\author{
Искра Тасевска Хаџи-Бошкова \\ Универзитет „Св. Кирил и Методиј“, Скопје \\ iskra.tasevska@flf.ukim.edu.mk
}

Текстот се занимава со истражување на проблемот на творењето на два различни јазика, што истовремено го актуализира и прашањето за припадноста на авторот. Фактот дека поетот Ерол Туфан е дводомен поет, кој е роден и дејствува извесно време во Македонија, а потоа и во Турција, умешно творејќи и на македонски и на турски јазик, не може да понуди темелно разрешување на загатката за поетовата онтолошка припадност, која во овој случај се изразува низ поседувањето на една специфична „номадска свест“, сфатена како хуманизам во неговиот изворен облик. Двојазичната поетска збирка Меланхолиja/Melankoli задира во она што се нарекува „транслингвално пишување“, односно „себепреведување“, како одраз на играта на различните јазични кодови, претставувајќи текст што е, всушност, динамична манифестација на повеќе аспекти од творечката личност. Во таа смисла, себепреведувањето, кое претставува можност за создавање нешто повеќе од едноставен јазичен еквивалент (бидејќи е во прашање креирање на творечкото себство на другиот јазик), недвосмислено го поставува проблемот на обликувањето на личноста наспроти нејзината конструкција во другиот (туѓ) контекст. Визијата за поетот преселник, транскултурализмот и авторовите поетички размисли ја прават поезијата на Ерол Туфан неодминливо четиво, кое е суштински дел од македонската литература, умешно избегнувајќи ги стапиците на лингвистичкото кодирање и неговите ограничувања.

Клучни зборови: дводомни автори, Ерол Туфан, себепреведување, транскултурализам, лиминалност 


\title{
MULTILAYERED CREATIVE ACTUALIZATION (THE POETIC DISCOURSE IN THE BILINGUAL COLLECTION MELANCHOLY BY EROL TUFAN)
}

\author{
Iskra Tasevska Hadži-Boškova \\ Ss. Cyril and Methodius University in Skopje \\ iskra.tasevska@flf.ukim.edu.mk
}

This paper analyses the problem of bilingual authorship by taking into account the question of the author's cultural affiliation and nationality. Erol Tufan is a poet that was born and raised in Macedonia, and after moving to Turkey continued to write in both languages (in Macedonian and Turkish). Since his poetic activity is manifested in two languages, the question about the poet's ontological affiliation is being raised, which in this case can be explained by the term "nomadic consciousness", understood as a purest form of humanism. The bilingual collection of poems Melancholy highlights the phenomenon called "translingual writing", or "self-translation", as a reflection of the game of various linguistic codes, creating a text which is dynamic manifestation of several aspects of the poetic personality. In that sense, self-translation is a possibility of manifesting something more than a simple language correlate, since it is an act of creating a poetic self into another language. This fact poses the problem of the construction of author's personality in the other (foreign) context. The vision of the poet as a nomad, migrant, the transculturalism and the author's poetic reflections make Erol Tufan's poetry an essential reading that belongs to the Macedonian literature, successfully avoiding the traps of linguistic coding and its limitations.

Keywords: bilingual authors, Erol Tufan, self-translation, transculturalism, liminality 


\section{1Јазикот и вдоменоста како специфични феномени}

Проблемот на творењето и творечките манифестации претставуваат исклучителен интерес на книжевната наука, која се осврнува и кон прашањата за припадноста и домовноста на авторите, особено кога се во прашање автори што егзистенцијално, духовно и поетички припаѓаат на различни културни средини. Поврзаноста на јазикот и домовноста на еден автор се исчитува како во рамките на еден одделен национален тек така и во однос на поширокиот контекст на светската литература, која како жариште ги прифаќа различните манифестации на творечкото себство. Оттука, се чини сосема оправдана констатацијата дека е поетот темелно невдомен, неомеѓен од контекстот и од јазикот (медиумот) кој ги актуализира неговите стремежи, со оглед на фактот дека „творечката егзистенција (...) е секојпат устремена кон повисокиот, повистинитиот, поубавиот Дом“ (Шелева 2005: 19). Прашањата што ги отвора творењето на еден автор во различни културни контексти се поставуваат во рамките на т.н. „методологија на дводомноста“, која своите анализи ги насочува главно кон истражување на условите, односно причините (Радически 2011: 133) што ги мотивирале авторите да живеат, односно да творат во различни национални и културни традиции. Поетот и неговиот свет се несомнено поврзани со средината што го обликува поетовото искуство или, подобро речено, со начинот на кој неговото искуство било формирано во одреден контекст, без притоа да се почувствува таквото дејствување, кое најчесто се затскрива зад доминантните обележја - јазикот и нацијата. Македонската литература од 19 век е добар пример за тоа како културната средина го обликувала искуството на авторите кои понекогаш биле принудени, во дадените околности, да творат во поинакви култури, кои, пак, ја наметнувале својата доминација преку употребата на нивниот јазик или национална припадност наспроти изворниот, македонски културен контекст. Иако тоа не е правило, стратегиите преку кои дејствуваат културните влијанија не се секогаш рамноправни, што често доведува до афирмирање или фаворизирање на една традиција во однос на друга.

Фактот дека поетот Ерол Туфан е доводомен поет, кој е роден и дејствува извесно време во Македонија, а потоа и во Турција, вешто творејќи и на македонски и на турски јазик, не може да понуди темелно разрешување на загатката за поетовата онтолошка припадност, која во овој случај се изразува низ поседувањето на една специфична „номадска свест“. Таа, на одреден начин, значи „неприфаќање на кој било идентитет како перманентен“ (Мојсова-Чепишевска 2020: 117). Оттука, поетските доживувања на Туфан се целосно осмислени низ аспектирањето на миграциите и на духот (меланхолијата) како трет суштински елемент на дијадата тело - душа, кој ја осветлува затскриената страна на „номадскиот субјект предаден на играта“ (Павловски 2020: 48). Природата на творечките стремежи на Туфан не може да се поистовети со романтичарската растргнатост на дводомните поети меѓу родниот крај и туѓината, бидејќи кај него станува збор за една специфична „културна 
боемија“ (Николовска 2021: 38), која претставува директен резултат од неговото одлично познавање на светскиот културен контекст, чиј дел недвосмислено претставува и самиот тој. Во таа смисла може да се прочита Туфановата фасцинација од творештвото на Радован Павловски, кој „не формира дом за себе во онаа традиционална статична форма во селото на осамениот врв. Неговиот дом е целиот свет, а клучот е песната и боемската природа на овој од Бога надарен громовник“ (Туфан 2021: 29). Оттука, јасно е дека проблемот на припадноста на поетското творештво на Ерол Туфан кон одреден културен контекст е, всушност, можност да се реактуализира космополитизмот како највисок човечки идеал, кој ги брише претпоставените граници во име на едно општочовечко обединување, во најдобрата смисла на тој збор. Феноменот наречен поетско себство ги надминува наметнатите граници на постоењето во одредена (и, најчесто, прецизно маркирана) културна средина, која се брани од туѓите влијанија, истакнувајќи ја својата специфичност и единственост. Слично како што ,јазичната алхемија“ на Туфан „фактографското го претвора во визуелно, имагинарно и фикциско“ (Куулавкова 2021: 85), така и неговата поезија го вмрежува јазичниот и културниот контакт во рамките на сеопштото светско наследство. Тој феномен се исчитува и низ визијата која се симулира преку двојазично пренесената поетска порака, што претставува особен дострел и специфичност на поетската збирка Meланхолија/Melankoli, како потесен предмет на нашата анализа.

\section{2 Во мрежата на јазичните кодови}

Творењето на два различни јазици, кои се чувствуваат како доволно пријатни и автентични престојувалишта во кои може да се отелотвори авторовото себство, претставува исклучителна привилегија на дводомните автори. Сепак, дури и тоа се покажува како недоволно, бидејќи индивидуалниот креативен потенцијал постојано се стреми да ги надмине претпоставените граници, независно од тоа каква е нивната природа. Во таа смисла, двојазичната збирка Меланхолија/Melankoli овозможува да ѝ се пристапи на поетската визија на различни начини, зависно од тоа кој е јазикот од кој тргнува читателот при допирот со книгата. Познавањето на двата јазика недвосмислено ни ја открива дискретната тајна што е импрегнирана во неа - постоењето на две различни поетски есенции. Во таа смисла, поетската збирка Mеланхолија/Melankoli задира во она што се нарекува ,трансјазично (транслингвално) пишување“, односно „себепреведување“ (Wilson 2012: 48-49), што покажува како играта на различните јазични кодови создава динамична корелација на повеќе аспекти од творечката личност. Во таа смисла, себепреведувањето, кое претставува можност за создавање нешто повеќе од едноставен јазичен еквивалент (бидејќки е во прашање креирање на творечкото себство на другиот јазик), недвосмислено го поставува проблемот на обликувањето на личноста наспроти нејзината конструкција во другиот (туѓ) контекст. Но, што се случува кога се работи за творец што не се наоѓа во вториот културен контекст како иселеник, туку е, всушност, повратник во таа култура, која е изворно (традициски) втемелена во неговото битие? Токму ова е случајот со Ерол Туфан, кој 
заминува во Турција во 1992 година од лични причини и со тоа ја обновува врската со семејната културна традиција. Тој процес несомнено остава траги врз неговата творечка личност, во која проникнува хетероглосијата како резултат од живеењето во различните културни сфери. Тоа значи и привилегија и одговорност за авторот, поставен и како толкувач и како културен медијатор (Wilson 2012: 58). И покрај тоа што, формално, ние сме навикнати да го гледаме процесот на преведувањето како нешто што значи втор живот за еден текст, обезбеден од друг, надворешен фактор, случајот со конвергенцијата на различните лингвистички димензии во едно творечко себство го поставува прашањето како повеќеслојно. Тука недвосмислено се преиспитува основаноста на тврдењето за креативната интенција како примарна и спонтана наспроти трансформирачкиот потенцијал на преводот (Benjamin 2007: 76-77). Пренесувањето на сопственото творечко себство на различни јазици и во поинакви културни контексти обезбедува извесен степен на слобода (Yu 2012: 74), во форма на трансгресија на општествените и на политичките рамки, со силата и живоста на пишаниот/изговорениот збор.

Себепреведувањето како егзистенција во две различни културни сфери значи и постоење во една лиминална и/или загрозувачка позиција. Како што истакнува Сузан Баснет (Bassnett 2007: 22), таа поставеност на преведувачот во т.н. „ничија земја“, која е отворена кон различни пречекорувања и бришења на границите, во суштина, ги преиспитува творечките интенции и можноста тој да го стабилизира сопственото себство среде импулсите што меѓусебно се проникнуваат. Во таа смисла, јасна е метафората на Бенјамин за т.н. ,јазик на вистината“, како средиште во кое се допираат различните идиоми и како теоретска можност за искажување на последниот збор, кој би ја исцрпил сета вистина во јазикот и од него. Специфичното движење на авторот среде јазиците во кои е втемелено неговото битие може да се согледа и низ исказот на Борхес, кој упатува на фактот дека „писателот ги создава своите претходници“ (Foulcault 1977), во смисла на начинот како појавата на едно дело ги модифицира претпоставените и стабилизирани вредности што им се припишуваат на делата од една литературната традиција (независно од тоа дали е таа перципирана од гледната точка на авторот), но и како тоа ги овозможува идните пројави. Активното пренесување на творечкото себство на повеќе јазици значи еден вид активен дијалог со светската културна традиција, која не може да се ограничи во својот дифузен и повеќенасочен тек. Tоа не е само израз на одредена политичка стратегија (во смисла на начинот како творечката интенција се врамува во, условно, туѓиот или поинаков контекст) туку тоа е и манифестација на неможноста да се омеѓи смислата, која често ги надминува границите поставени од јазичните средства. „Верноста и слободата“" (Benjamin 2007: 79), како две противречни тенденции што мора да се рефлектираат при пренесувањето на значењето од еден јазичен систем во друг, во суштина значат можност за реинтерпретирање, ослободување на смислата од стегите на едниот и на другиот јазик во идеалниот меѓупростор на ,чистиот јазик“, во кој би се исцрпиле сите конотации на еден збор. Тоа е таа „еквиваленција во разликата“ при меѓујазичниот превод за која зборува Јакобсон (Jakobson 2000: 114), а која, во суштина, значи дека степенот на 
преводливоста на еден текст е врамен во стратегиите и во параметрите на пошироката културна средина за која станува збор.

\section{3 Поетското себство како повеќеслоен феномен}

Проблемот на дијалогот на двете културни сфери во творечкото себство - во смисла на етичката насоченост на себството, кое е пошироко од субјективното ,jас“ (Рикер 2004: 189), вдомено во нив на речиси идентичен начин, можеме да го согледаме во редица песни од збирката Mеланхолијa/Melankoli. Ocобено е интересно да се разгледа начинот како тие ја поставуваат под прашање корелацијата меѓу творењето и пренесувањето на значењето на друг јазик, особено што и двете дејства се втемелени во истата личност. Притоа, во песните е минимално присутна онаа анксиозност од пренесувањето на себството во различните идиоми (Yu 2012: 68), која се поврзува со фактот дека перцепцијата на доминантната културна средина е секогаш наклонета кон творење и изразување во рамките на едниот, соодветен и избран јазик. Тоа би значело дека творечкиот импулс недвосмислено се идентификува со припадноста кон тој (еден) јазик на кој авторот чувствува дека е природно (нужно) да се твори. Но, што кога авторот е втемелен подеднакво во повеќе културни традиции и не може да се каже која била првата во која се родил како творец? Ова е прашањето што како клучно се отвора при читањето на поетската збирка на Ерол Туфан, а постоењето на паралелни текстови на двата јазика (македонскиот и турскиот) ја засведочува афирмативната визија за неограниченоста на творечката интенција. Поетот се поставува како меѓник, во чие средиште флуктуираат различните културни влијанија, кои се изразуваат на непосреден и иновативен начин.

Визијата за двата истовремени тека, обликувани од историски блиските културни традиции, може да се дофати дури и само ако се погледне изданието на збирката. Станува збор за еден буквален и метафоричен приказ на корелацијата меѓу лицето и опачината, втемелена во природата на сите нешта. Како што се тие дел од една единствена целина така и песните на двата јазика се дел од иманентната поетска визија. Притоа, она што особено импресионира е начинот на кој поетската имагинација се преобликува, не задирајќ́ толку во природата на лингвистичките релации меѓу двата јазика колку во интенцијата на авторот да врами иновативни елементи во означувачкиот процес на соодветните јазици. Тука повторно се отвора прашањето за потребата од таквото сопоставување на двата идиоми, кога секогаш постои можноста да се втемели искажаното во рамките на еден доминантен јазичен (културен) контекст. Делумно објаснување на овој процес ни нудат песните „Преселник“ и „Камчето од Вардар“. Песната „Преселник“ го содржи поимањето на преселникот како човек што самиот го избира својот егзил, барајќи го ,еликсирот на вечниот живот“ (Туфан 2020: 38), додека во песната на турски јазик (“Göçmen artist”) се истакнува фактот дека е тоа „уметникот преселник“. Тој елемент, кој изгледа незначително, во суштина, предизвикува преосмислување на кружното движење на преселникот, кој во младоста се преселува, бидејќ́ е поттикнат од копнежот по непознатото и по величественото, а потоа повторно се враќа 
назад, потврдувајќи ја неможноста да се оддели од татковата куќа, односно од родното огниште. Оваа претстава за цикличното движење меѓу домот и непознатото, без нивно конечно определување на оската на спротивностите, како метафора за животот воопшто, го втемелува и поимањето за паралелното живеење во различните идиоми. Развиеноста на структурата на песната на турски јазик сведочи и за дискретната автопоетика, која е пренесена низ поетската слика за вечната потрага на уметникот на зборот по сопственото творечко себство. „Taşıdığım umudu ateşe döndüremedim, dedi / Dolaştım, o sahne senin bu sahne benim / Nice rollere büründüm / Kendi yüzümü bulamadım“ (Tufan 2020: 40). Во тој контекст се истакнува метафоричното „обвивање (нагрнување) со различни ролји (улоги)“, кои го истакнуваат поетовото хибридно себство и неговата крајна невтемеленост.

Феноменот на поетот преселник, чија судбина е завештание од некои претходни времиња (бидејќи тој е предодреден да мине голгота), е фасцинантно предаден во песните „Камчето од Вардар“ / "Vardar' da bir çakıl taşı”. Тука се отвора и прашањето за пресоздавањето на текстот при јазичниот трансфер, како акт на читањето и на пишувањето (Rossi 2018: 46), што задира во клучните аспекти на реконструирањето на изворникот и на преведениот текст (што во случајов потешко се одредува, потенцирајќи ги бесконечните двонасочни релации). Претставата за начинот како текстот комуницира со културната средина кон која е насочен, во овој случај е симулирано преку одредени директни сигнали. Таква е, на пример, метафората за истекувањето на водата како враќање кон извориштето на цивилизациите, кое во песната на македонски јазик е претставено преку вградувањето (врамувањето) на наносот (поетовото себство) во културната традиција, позната на овие простори од Александар III Македонски до денес. Преку синегдохата (камчето од Вардар) е пренесена свеста за судбинската одреденост на редица македонски жители од Полошко, кои се појавуваат како средишта за интерференцијата на цивилизациите. Во таа смисла, текстот корелира со актуелните концепти што се примарни и активни во свеста на читателот од македонската средина. Од друга страна, во песната на турски јазик Туфан истакнува еден поинаков феномен, кој за турскиот читател е поиндикативен во однос на значењето на Александар III Македонски за светската култура. Во случајов, тоа е метафоричното дополнување што „камчето“ го прави кон египетскиот обелиск, поставен во 4 век во Константинопол (Истанбул) од страна на римскиот император Теодосиј I, со што „наносот“ се врамува во напластеното културно наследство на турската културна сфера. Истанбул како средиште на безброј импулси од различни културни средини и периоди овозможува афирмирање на ваквите процеси. Во овој контекст можат да се прочитаат нијансите на специфичната интеркултурна комуникација, која во првиот случај значи продолжување на текот на движењето од извориштето кон обновениот центар на случувањата (Истокот), а во вториот врамување во постојниот хибриден тек на напластени културни влијанија во еден поширок регион.

Визијата за творечкиот процес доминира во голем број песни од збирката Меланхолија, но во тој поглед е особено илустративна истоимената песна. Таа е автопоетичка во својата суштина и манифестира дискретни квалите- 
ти на ниво на стил и на поетски израз, зависно од лингвистичкиот медиум низ кој се пренесува. Тука се забележува она што се нарекува модус на читањето, кој е особено специфичен за начинот како се чита текстот кога тој доживува премин од еден лингвистички феномен кон друг. Во таа смисла, пренесениот текст од еден јазик на друг (литерарен и нелитерарен) може да биде прочитан низ потенцирање или пренебрегнување на фактот дека е преведен (Boase-Beier 2014: 28). Со оглед на својствата на поезијата на Туфан, која ја замаглува границата меѓу она што се нарекува изворен текст и превод, песната „Меланхолија“ завлегува конкретно во суштината на творечкиот процес. Песната на македонски јазик ја потцртува необичната природа на меланхолијата, која го обзема творецот како креативен порив, манифестиран во согласност со нејзината необична појава - „парчосана нимфа“, односно „жена со црн превез на лицето и жолт тен“. Наспроти таа развиена претстава, во истоимената песна на турски јазик се забележува ставањето акцент на дејствувањето, односно на феноменот на внатрешниот дијалог, кој го поттикнува појавата на меланхолијата. Она што феминистичките критичарки го разгледуваа како доминантен аспект на меланхолијата, сфатена во врска со исклучително потенцираната машкост и односот со суперегото (Schiesari 1992: 92), може да се прочита и во творештвото на Туфан, и тоа на два начини. Од една страна, тоа е потврдувањето на творечкото себство наспроти женската природа на меланхолијата, а од друга страна, тоа е активната проекција на суперегото (односно на потенцираниот интелектуален потенцијал, умот, кој го „продлабочува“ внатрешниот глас на творецот за тој да произведе вистинска размена, т.е. дијалог). Во таа смисла, меланхолијата како феномен во поетската визија на Туфан е нешто повеќе од едноставен поттик за манифестација на творечкиот нагон и потенцијал, независно од родовите аспекти. Таа ја проблематизира авторовата втемеленост во светот, но и во неговиот симболичен ред, кој има тенденција да ги отфрла личностите и појавите што се стремат да егзистираат некаде на меѓата, како невтемелени, хибридни, разнолики. Допирот со меланхолијата за авторот значи одлука да се предаде на незапирливиот творечки порив, кој го засилува постојаното преиспитување на сопствените сили и можности.

Одлична метафора за поетот и за значењето на зборот претставуваат песните „Молк“ / “Sükût”. И покрај тоа што феноменологијата на зборот е откриена во светлината на поврзувањето на луѓето и животот воопшто, зборот ја потенцира потребата на човекот од молкот, кој, како јадро во кое се генерира поривот, ги определува суштествените настани од човековиот живот. „Повратокот е секогаш поплочен со молк / Kavuşmamız için sükutu beklemeliyiz“" (Туфан / Tufan 2020: 11, 12). При споредбата на овие два стиха, израснува една нијанса на значењето, која зборува индиректно за начинот на кој се рефлектираат поимањата на Туфан за овој мошне важен феномен. Во првиот пример молкот е нужен за враќањето, буквално и метафорично, кое на мошне видлив начин се вткајува во поетиката на преселбите на Туфан. Во вториот случај, пак, молкот недвосмислено ја условува средбата, не само на две битија во животната стварност туку и на едно креативно ниво, што индиректно упатува на средбата на творечкиот гениј со повисоката инстанција (суперегото / Бог / 
меланхолијата), како желба за етаблирање на неговата исклучителна позиција во културната средина, која не може да се определи на очекуваниот начин (просторно или временски). Оттука, во песните „Исчекување (на кандидатот за поет) / Bekleyiş“, Туфан ја разоткрива човековата потреба да го идентификува или да го отелотвори творечкото себство, кое ја трансцендира таквата перспектива и се поставува само како една „можност“ за поезија, за стихови. Песната повторно ја варира поетовата егзистенција на две рамништа, поставувајќ и ја, од една страна, во врска со молкот, а од друга страна, во дискретна релација со „новиот збор, создаден од љубовниот танц / на ветрот и карпата / измиен од ударите на крупните капки вода“ (Туфан 2020: 14). Тој збор е, во суштина, сфатен како изворен, недопрен, жив (“sahipsiz, dokunulmamış, canlı söze varmak istiyorum”), што фрла светлина врз целокупниот творечки процес, кој трага по неистрошени, нови, необични зборови и контексти. Песната истовремено ја потенцира лиминалната позиција на уметникот, кој е постојано во ситуација да биде „номиниран кандидат за поет / и вечен бдејач над туѓите радости“. Таквото сфаќање на чекањето како еден чекор кон потврдувањето, односно кон крајната вистината, независно од нејзината релативност, во фокусот ја поставува креацијата како модус на постоење, нејзината вечна присутност и потенцијал кој не може да се исцрпи.

Една интересна компонента во поетското доживување на Туфан претставува дескриптивноста, која во ниеден случај не е цел самата за себе. Тој елемент во неговата поетика е секогаш врамен во еден подлабок егзистенцијален контекст, кој отвора суштински, т. е. општочовечки прашања за животот, смислата и постоењето. Индикативна е, во тој контекст, песната „Зимска птица“, во која претставата за зимската птица што не заминува во потоплите краишта ја дополнува сликата за поетот, кој е оставен на милост и немилост токму поради тоа што ги преиспитува клучните феномени на човековата егзистенција. Песната на турски јазик (“Kış kuşu”) ja преобликува таквата проблематична поставеност на поетот во една издиференцирана слика за творецот, кој е целосно посветен на верноста кон вистинските вредности, сфатена како бегство од животот и од предметната стварност. “Аh, ne desem ki ben / Gerçek hayattan kaçan / Kitaplar ve düşünceler / Dünyasında / Gönüllü köleliğe razı olan?” (Tufan 2020: 27). Слично, во песните „Дрво“ / "Аğaç”, визијата за поетовата состојба и дејствувањето на имагинацијата е метафорично отсликана преку претставата за дрвото, кое се појавува како елемент во поетовата фантазија и во соништата, а всушност, ја носи неговата душа, во смисла на анимистичките претстави и нивните значења. Дрвото e, истовремено, метафора за изминатото време, за истрајноста пред искушенијата, за самувањето на човекот и на поетот, добивајќи ги обележјата на едно бесконечно трагање и прикрепување на својата смисла кон трагите од различните облици, обележени со протекувањето на времето. Поетот е „човекот со три души“, чие постоење е определено од проникнувањето на трите димензии што бесконечно се приближуваат, никогаш целосно не спојувајќи се. Поетската егзистенцијата е секогаш на едно повисоко ниво, како трансценденција во „долината на сенките“, односно како совршена кулминација на амбиваленцијата на телото и душата. 


\section{4 Поезијата како втор живот}

Импресивниот потенцијал на уметничкото сликање и доживување на Ерол Туфан сведочи за моќта на неговиот поетски збор, кој го напушта вообичаениот контекст во кој се појавува и бесконечно ја варира смислата. Во неговата двојазична поетска збирка, корелацијата на двата идиоми подразбира и активна релација на двете претставени стварности. Притоа, Туфан ги избегнува стапиците на „одомаќинувањето“ и „отуѓувањето“(Venuti 1995: 20) на текстот во променетиот контекст, што значи дека кон поетската порака не се прикрепени никакви дополнителни значења што ќе симулираат одреден доминантен културен или национален светоглед. Неговата поетска визија едноставно ги следи параметрите по кои е специфичен одреден културен контекст, претворајќи ги во функционални читателски сигнали. Нејзината моќ за обликување на искуството е импресивна и овозможува поглед навнатре, кон бескрајните длабочини на ониричкото, заумното, натсетилното.

\section{Библиографија}

Мојсова-Чепишевска, В. (2020). Повторно создавање дом (некаде на поетскиот меридијан Вруток - Беаз Куле или на поетскиот напоредник Скопје - Истанбул). Во

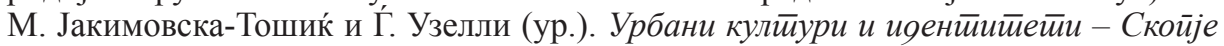
и Истианбул: Зборник на йруяови оя мег̆унарояен симйозиум, 117-127. Скопје: Институт за македонска литература. [Mojsova-Čepiševska, V. (2020). Povtorno sozdavanje dom (nekade na poetskiot meridijan Vrutok - Beaz Kule ili na poetskiot naporednik Skopje - Istanbul). In M. Jakimovska Tošiḱ and Ǵ. Uzelli (eds.). Urbani kulturi i identiteti - Skopje i Instanbul: Zbornik na trudovi od meǵunaroden simpozium, 117-127. Skopje: Institut za makedonska literatura.]

Николовска, К. (2021). Раскошен поетско-есеистички мозаик (кон „Несоници“ од Ерол Туфан). Сйожер, год. XIV, бр. 138: 38-39. [Nikolovska K. (2021). Raskošen poetsko-eseistički mozaik (kon „Nesonici“ od Erol Tufan. Stožer, god. XIV, br. 138: 38-39.]

Павловски, М. (2020). Балканскиот син Ерол Туфан. Во Ерол Туфан. Меланхолија / Melankoli. Скопје: Книгоиздателство МИ-АН. [Pavlovski, М. (2020). Balkanskiot sin Erol Tufan. In Erol Tufan. Melanholija/ Melankoli. Skopje: Knigoizdatelstvo MiAn.]

Радически, Н. (2011). Прея алфа и йрея яелйа: ӣрилози за макеяонскайа яруг̄ојазична лийерайура. Скопје: Македоника литера. [Radičeski, N. (2011). Pred alfa i pred delta: prilozi za makedonskata drugojazična literatura. Skopje: Makedonika litera.]

Рикер, П. (2004). Сойсииво као яругии. Београд: Јасен. [Riker, P. (2004). Sopstvo kao drugi. Beograd: Jasen.]

Туфан, Е. (2020). Меланхолија. Скопје: Книгоиздателство МИ-АН. [Tufan, Е. (2020). Melanholija. Skopje: Knigoizdatelstvo Mi-An.]

Туфан, Е. (2021). За поетиката на Радован Павловски - четворица автори (дел од текстот „Азискиот дел на велеградот на Босфор“ ). Сйожер, год. XIV, бр. 138: 29. [Tufan, E. (2021). Za poetikata na Radovan Pavlovski - četvorica avtori (del od tekstot „Aziskiot del na velegradot na Bosfor"). Stožer, god. XIV, br. 138: 29.]

Ќулавкова, К. (2021). Интертекстуални „несоници“ (За поетската книга Несоници - 99

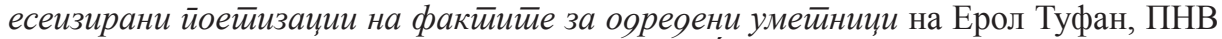
публикации, Скопје 2020). Синиеези, 51: 84-85. [Ḱulavkova, К. (2021). Intertekstualni 
„nesonici“(Za poetskata kniga Nesonici - 99 eseizirani poetizacii na faktite za odredeni umetnici na Erol Tufan, PNV publikacii, Skopje, 2021). Sintezi, 51: 84-85.]

Шелева, Е. (2005). Дом / ияенииийей. Скопје: Магор. [SSeleva, Е. (2005). Dom / identitet. Skopje: Magor.]

Bassnett, S. (2007). Culture and Translation. In P. Kuhiwczak and K. Littau (eds.). A Companion to Translation Studies, 13-23. Clevedon, Buffalo, Toronto: Multingual Matters Ltd.

Benjamin, W. (2007). The Task of the Translator (An Introduction to the translation of Baudelaire's "Tableaux Parisiens"). In H. Arendt (ed.). Illuminations: Essays and Reflections, 69-82. New York: Schocken Books.

Boase-Beier, J. (2014). Stylistic Approaches to Translation. London and New York: Routledge.

Foucault, M. (1977). Language, Counter-Memory, Practice (Selected Essays and Interviews). Ithaca, New York: Cornell University Press.

Jakobson, R. (2000). On Linguistic Aspects of Translation. In L. Venuti (ed.). The Translation Studies Reader, 113-118. London and New York: Routledge.

Rossi, C. (2019). Literary translation and disciplinary boundaries (creative writing and interdisciplinarity). In K. Washbourne and B. V. Wyke. The Routledge Handbook of Literary Translation, 42-57. London and New York: Roultedge.

Schiesari, J. (1992). The Gendering of Melancholia. Ithaca and London: Cornell University Press.

Tufan, E. (2020). Melankoli. Üsküp: Mİ-AN Kitap Yayınevi.

Venuti, L. (1995). The Translator's Invisibility (a history of translation). London and New York: Routledge.

Wilson, R. (2012). Parallel creations: Between self-translation and the translation of the self. In R. Wilson and L. Gerber (eds.). Creative Constraints (Translation and Authorship), 47-65. Clayton: Monash University Publishing.

$\mathrm{Yu}$, O. (2012). Giving birth to the self: On self-translation. In R. Wilson and L. Gerber (eds.). Creative Constraints (Translation and Authorship), 67-75. Clayton: Monash University Publishing. 
